\title{
Docetaxel hydrate induces apoptosis and suppresses tumorigenesis of oral Burkitt's lymphoma cells (in vitro and in vivo studies)
}

\author{
Supriatno ${ }^{*}$ \\ 'Department of Oral Medicine, Faculty of Dentistry Gadjah Mada University, Indonesia
}

\begin{abstract}
Introduction: Burkitt's lymphoma (BL) is one of the tumours with high malignancy and rapid cell growth, derived from B-cell lymphoma. BL typically found in children at dengue-endemic and HIV-AIDS areas with low socioeconomic levels. This study was aimed to analyse the induction of apoptosis and the suppression of tumorigenesis of oral Burkitt's lymphoma (Raji) cells using docetaxel hydrate in vitro and in vivo. Methods: In the present study, the pure experimental laboratory with post-test only control group design was carried out. Raji cell cultures were incubated with docetaxel hydrate by doses of $0,1.25 \times 10-2$, $2.5 \times 10-2$, and $5.0 \times 10-2 \mathrm{M}$; and IC50 carboplatin $(3.1 \times 10-6 \mathrm{M})$ as a positive control. Induction of apoptotic was analysed by double staining of acridine orange-ethidium bromide. Tumorigenesis assay was performed by inoculating Raji cells in nude mice flanks at $1 \times 106$ cells/mice. Tumour treatment was delivered by various doses of docetaxel hydrate peroral. Results: Apoptosis cells were significantly increased in Raji cells treated with docetaxel hydrate by doses of $2.5 \times 10-2$ and $5.0 \times 10-2 \mathrm{M}$. The tumour volume in mice given doses of $2.5 \times 10-2$ and $5.0 \times 10-2 \mathrm{M}$ was markedly decreasing compared to control (dose of 0 ). Conclusion: Docetaxel hydrate has a high antitumour potency by inhibiting tumorigenesis and increasing apoptosis of Burkitt's lymphoma cells.
\end{abstract}

Keywords: Docetaxel hydrate, double staining, Burkitt's lymphoma cell, apoptosis, tumorigenesis

p-ISSN 1979-0201, e-ISSN 2549-6212; Available from: http://jurnal.unpad.ac.id/pjd/article/view/18102

DOI: 10.24198/pjd.vol31no1.18102

Submission: Jul 31, 2018; Accepted: Feb 27, 2019; Published online: Mar 29, 2019

\section{INTRODUCTION}

Burkitt's lymphoma (BL) is one of the aggressive malignant tumours derived from lymphoid and covers $3-5 \%$ of all lymphoma tumours. BL attacks $40 \%$ of children with non-Hodgkin lymphoma (NHL). ${ }^{1}$ The highest incidence of $\mathrm{BL}$ is found in malaria endemic and HIV-AIDs areas in the equatorial regions of Africa and Papua-New Guinea, with a $50-70 \%$ of all malignancies occurring in the child population. ${ }^{2} \mathrm{BL}$ is characterised by a chromosome translocation between the proto-oncogene c-myc and one of the immunoglobulins (Ig) loci. ${ }^{3}$ It was reported that increased aggressiveness of $\mathrm{BL}$ cells was firmly related to the presence of EpsteinBarr virus (EBV). ${ }^{4}$ The mortality rate of children

"Corresponding author: Supriatno, Department of Oral Medicine, Faculty of Dentistry Gadjah Mada University, Indonesia. Denta 1, Sekip Utara, Yogyakarta, Special Region of Yogyakarta, Indonesia, 55281. Phone: +6281931363797; Email: supriatno_fkg@ugm.ac.id 
with $\mathrm{BL}$ is growing from year to year, especially in children living in slums with unhealthy nutritional factors. ${ }^{2}$ It was reported that Burkitt's lymphoma patients recorded at the Cipto Mangunkusumo Hospital Jakarta from 2001 - 2006 were as many as 7 patients ( 6 males, 1 female); ages ranged from 0-15 years old. ${ }^{5}$ Data from patients with Burkitt's lymphoma in Indonesia is still unclear. Based on the reports, development of more effective and potent therapies for oral Burkitt's lymphoma must be continued, one of them using the docetaxel hydrate agent. ${ }^{6}$

Docetaxel hydrate is a taxoid family antineoplastic agent used for the treatment of several types of human cancers. It is also an anticytostatic agent that has in vitro and in vivo effects. ${ }^{6}$ Docetaxel hydrate is reported to have growth inhibition for various types of cancer cells including prostate cancer, breast, oral, and stomach..$^{6-9}$ Docetaxel hydrate suppresses cancer cells by interfering with the microtubule function that is essential for cell survival and leading to apoptosis or cell death. ${ }^{10}$

Apoptosis is the primary physiological process that contributes to the maintenance of cellular homeostasis. ${ }^{11}$ Apoptosis is generally characterised by different morphological and energy depending on the biochemical mechanism. Apoptosis plays an essential role in various life processes in response to DNA damage, including normal cell turn over, development of immune system function, hormone-dependent atrophy, embryonic development and chemical-induced cell death. ${ }^{12}$ Disruption apoptosis affects many human conditions including neurodegenerative disease, ischemic damage, autoimmune disorders and various types of cancer. ${ }^{11,13}$ Apoptosis is also a natural process that can remove unwanted, excessive or damaged cells from multicellular organisms. Different to cancer cells, the presence of multiple genetic disorders and cellular stress in malignant transformation will activate proapoptotic agents. ${ }^{14}$ The ability to regulate living cells and/or dead cells is a potentially beneficial therapeutic target. ${ }^{12}$ Therefore, the study focused on explanation and analysis of fast-moving apoptotic signalling pathways. Although many of the major apoptotic proteins have been identified, the molecular mechanisms remain unclear.
Tumorigenesis is the formation of tumours derived from healthy cells turned into tumour cells. Its process is characterised by mutations and changes in cellular, genetic, epigenetic and abnormal cell divisions. ${ }^{6}$ Generally, there is a balance between proliferation and programmed cell death (apoptosis) to maintain the integrity of cells, tissues and organs. ${ }^{15}$ In contrast, there is no balance between proliferation and apoptosis in cancer cells. Cell proliferation process is faster than apoptosis which results in uncontrolled cell division. ${ }^{6}$

In this study, apoptotic induction of Burkitt's lymphoma cells treated with various concentrations of docetaxel hydrate was analysed by double-staining acridine orange-ethidium bromide (AO-EB), and tumorigenesis assay was performed in nude mice. This study was aimed to analysed the induction of apoptosis and the suppression of tumorigenesis of oral Burkitt's lymphoma (Raji) cells using docetaxel hydrate in vitro and in vivo.

\section{METHODS}

The true experimental laboratory with the posttest only control group design was performed in this study. Burkitt's lymphoma (Raji) cells was delivered from Department of Paracitology, Faculty of Medicine, Universitas Gadjah Mada, with cell characteristic is ATCC CCL-86 B-lymphocyte (USA).

Cells and cell cultures, Burkitt's lymphoma (Raji) cells were cultured in Dulbecco's modified eagle medium (DMEM, Sigma-Aldrich, USA) supplemented with $10 \%$ fetal calf serum (FCS, Moregate BioTech, Australia), $100 \mu \mathrm{g} /$ $\mathrm{ml}$ streptomycin, and 100 units $/ \mathrm{ml}$ penicillin (Invitrogen Corp., USA). BL cells were incubated in $95 \%$ humidity and $5 \% \mathrm{CO}_{2}$ at $37^{\circ} \mathrm{C}$.

Apoptosis induction assay using AO-EB staining, Ethidium bromide-acridine orange stock solution was prepared from $50 \mathrm{mg}$ ethidium bromide plus $15 \mathrm{mg}$ acridine orange dissolved in 1 $\mathrm{ml} 95 \%$ ethanol and $49 \mathrm{ml}$ of distilled water. Next, from solution stock was taken $1 \mathrm{ml}$ of solution and diluted in phosphate buffer silane (PBS, Nacalai, Japan) with ratio 1: 100. Microplate 24 wells was prepared and put in the cover glass at each well. Raji cells ( 2 × 104 cells / wells) from 
the incubator were cultured in a well contained DMEM $10 \%$ fetal calf serum (FCS). Subsequently cells were incubated for 24 hours at $37^{\circ} \mathrm{C}$ and $\mathrm{CO}_{2}$ $5 \%$. After incubation, medium was aspirated and each well was given new DMEM 10\% FBS which has been added various concentration of docetaxel hydrate. Cells were incubated for 48 hours. After that the glass cover at the bottom of the well was removed and placed on the object glass according to the docetaxel hydrate doses label. All samples were stained with a combination of $10 \mu$ l ethidium bromide-acridine orange solution by dropping on a glass cover for 20 minutes. All preparations were observed under a fluorescence microscope with magnification 40x. Viable cells appeared bright green, while the yellow-red cells showed the apoptotic cells. Apoptosis cells were measured by manual standard procedure (unit: \%).

Tumorigenesis assay, Cultured Raji cells (1x106 cells/mice) were inoculated on nude mice flank using $1 \mathrm{ml}$ injection syringe. After growing the tumor (diameter $\pm 2 \mathrm{~cm}$ ), mice divided into 5 groups, each group was 3 mice: negative control (dose 0 ), $1.25 \times 10^{-2} ; 2.5 \times 10^{-2} ; 5 \times 10^{-2} \mathrm{M}$, and IC50 carboplatin $\left(3.1 \times 10^{-6} \mathrm{M}\right)$ as a positive control. Treatment was started on day 0 at intervals of 3 days.The suppression of tumorigenesis was measured by tumor volume with formula: $V=0.4$ $x \mathrm{~L} \times \mathrm{W}^{2}$. Statistical analysis, data was analysed using one-way ANOVA followed by Post Hoc (LSD) with 95\% significance level. The analysis program was carried out by SPSS 16.00 software (SAS Institute Inc., Cary, NC, USA).

\section{RESULTS}

The induction of cell apoptosis treated by docetaxel hydrate has been investigated in vitro on oral Burkitt's lymphoma cells through a double staining analysis of AO-EB. Docetaxel hydrate was significantly increased the apoptosis cells compared with that of negative control. Apoptosis cell was also occured in Raji cells induced by carboplatin IC50 which serves as a positive control. Based on Figure 1A, viable cells appeared bright green color, while apoptotic cells showed a yellow-orange color. The activity of cells apoptosis was markedly increased in the docetaxel hydrate treatment. The highest dose of docetaxel has the highest apoptotic activity.

It was also found that positive controls had higher apoptotic activity than the highest docetaxel $\left(5.0 \times 10^{-2} \mathrm{M}\right)$ dose (Figure $\left.1 \mathrm{~B}\right)$. The cell apoptotic activity was started from doses of 1.25 $\times 10^{-2}$ to $5.0 \times 10^{-2} \mathrm{M}$.
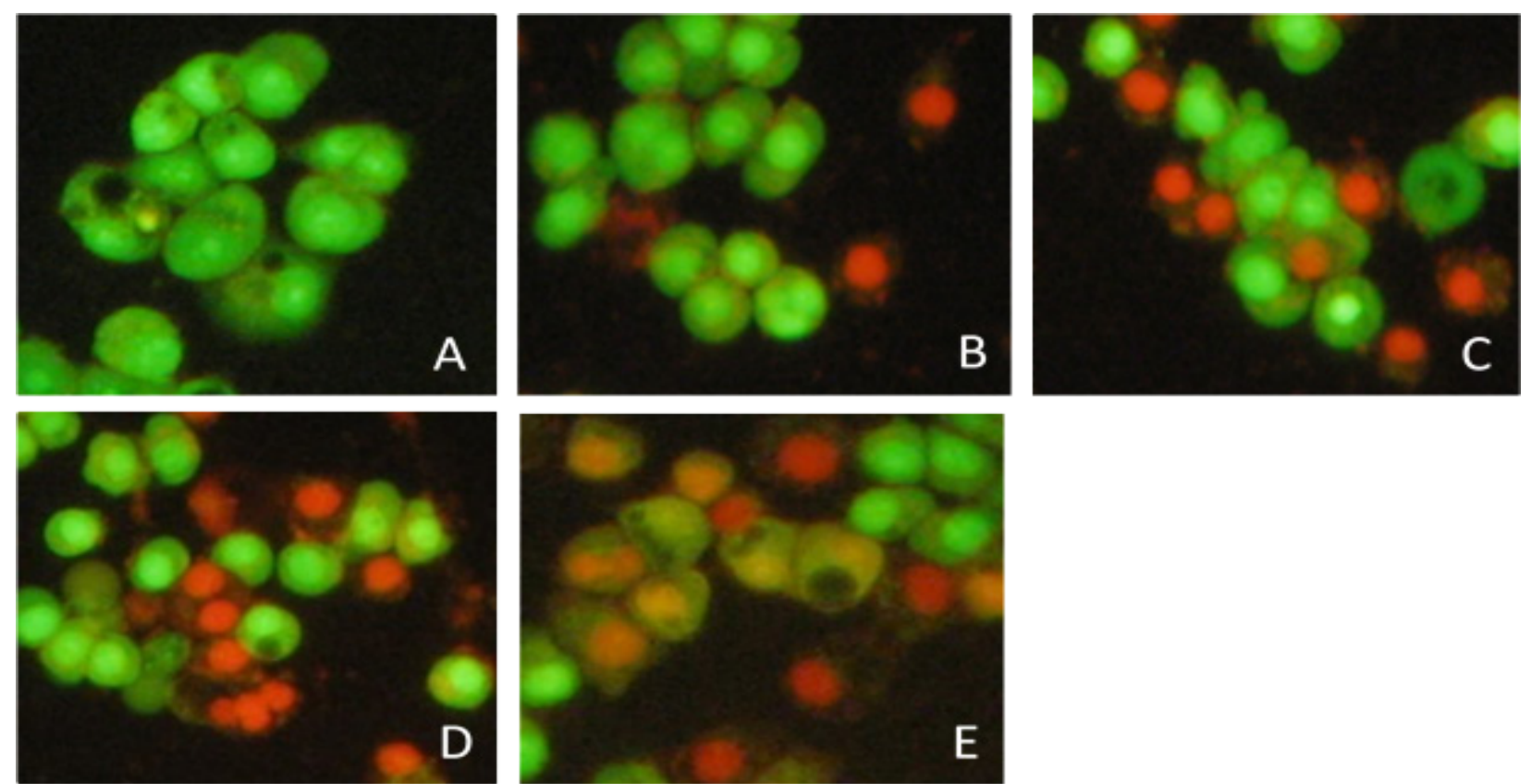

Figure 1A. Apoptosis Raji cells were treated with various concentrations of docetaxel hydrate; A. negative control; B. concentration $1.25 \times$ 10-2 M.; C. Concentration 2.5 x 10-2 M.; D. Concentration 5.0 x 10-2 M.; E. Positive control carboplatin IC50 (3.1 x 10-6 M).

(Green color: viable cell and yellow-orange color: apoptotic cells) 


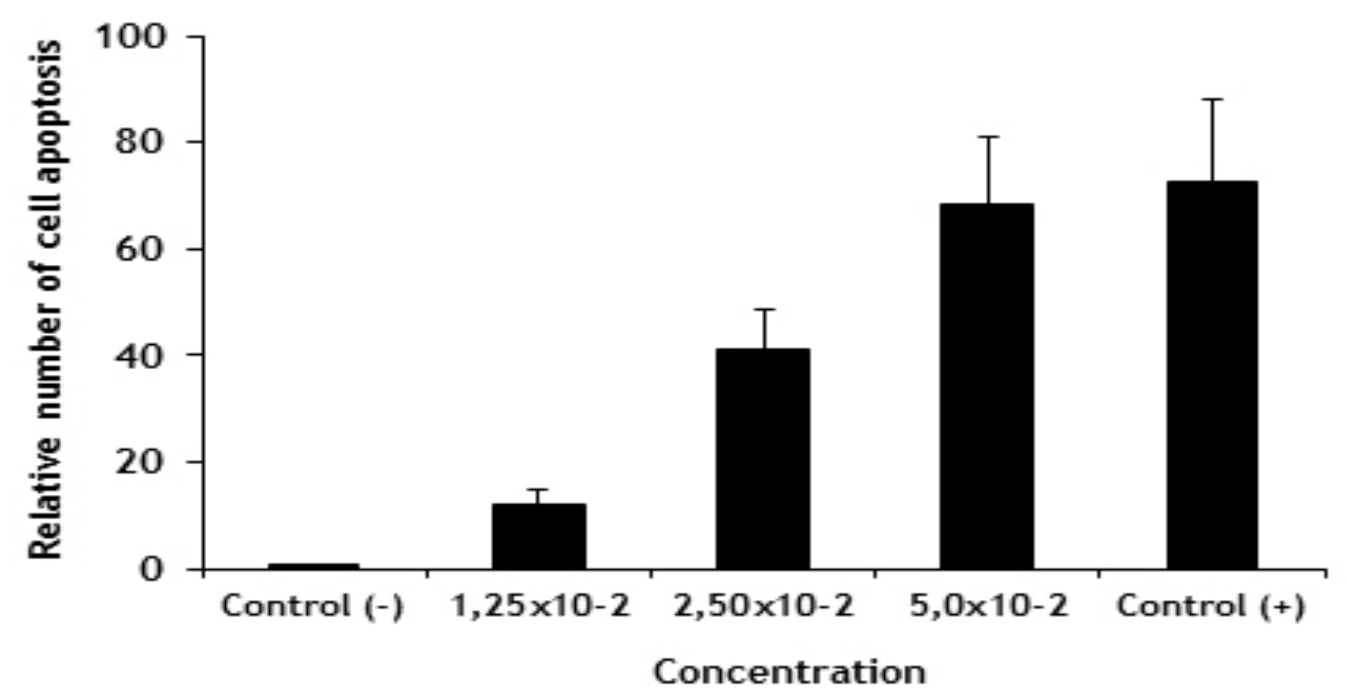

Figure 1B. Relative number of cell apoptosis treated with various concentrations of docetaxel hydrate of [**p $<0.01$; compared with control (-),one-way Anova, concentration unit: M]

In vivo tumorigenesis assay revealed Raji cells treated with various concentration of docetaxel hydrate had an increasing suppression of tumor growth in accordance with the elevating doses of docetaxel hydrate. Based on Figure 2, the difference in tumor volume size begins on the $6^{\text {th }}$ day of treatment.

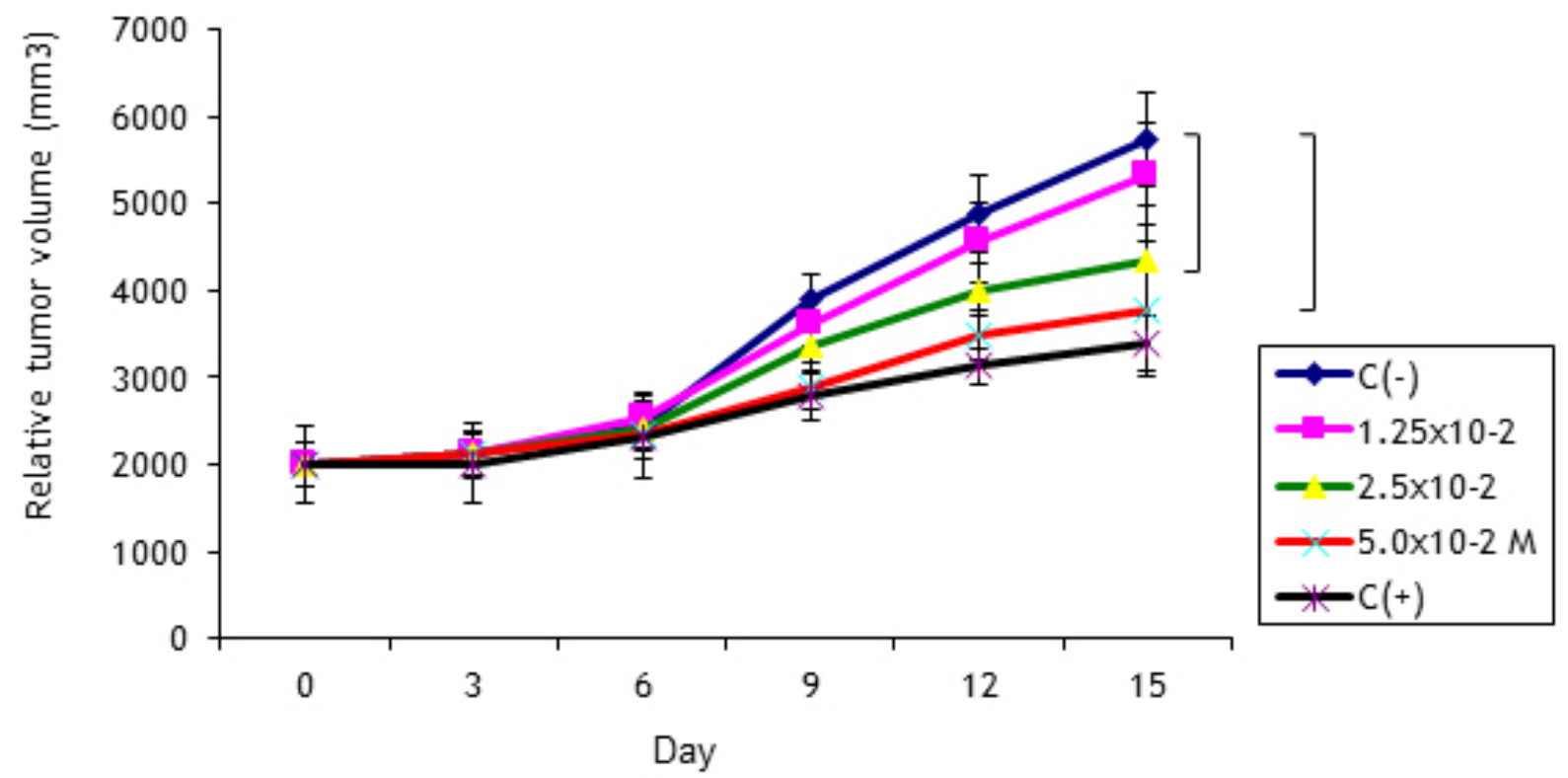

Figure 2. Relative tumour volume of Burkitt's lymphoma post-treatment with various concentrations of docetaxel hydrate.

$$
{ }^{* *} \mathrm{p}<0.01 \text {; one-way Anova }
$$

Positive control [carboplatin IC 50 (3.1 x $\left.10^{-6} \mathrm{M}\right)$ ] showed the strongest inhibition of tumor volume, but not significant when compared with concentration of $5.0 \times 10^{-2} \mathrm{M}$. The potential of cell tumorigenesis inhibition treated with docetaxel hydrate $5.0 \times 10^{-2} \mathrm{M}$ was detected at $62.5 \%$ compared to negative control at day 15 .

\section{DISCUSSION}

The inhibition of Burkitt's lymphoma cell growth using various concentration of docetaxel hydrate through in vitro apoptosis and in vivo tumorigenesis analysis was carried out. The activity of Raji cell apoptosis treated with docetaxel concentration 
of $5.0 \times 10^{-2} \mathrm{M}$ and $2.5 \times 10^{-2} \mathrm{M}$ through double staining analysis was increased $68.5 \%$ and $41.2 \%$, respectively compared with that of negative control. These result suggested that docetaxel hydrate has a strong activity in elevating cell apoptosis, although the potency of apoptosis activity was not stronger than positive controls. This data suggested that carboplatin IC50 used as a positive control was to have stronger sensitive to Raji cells or carboplatin concentrations used were still too high (carboplatin IC50 concentrations used in this study were taken from IC50 head and neck, colon, breast and uterine cancer).

The most important results above indicated an increase in Raji apoptotic cell activity treated with various concentration of docetaxel hydrate (Figure 2) followed by increased the proliferation and cell migratory suppression in accordance with increasing docetaxel hydrate concentration. These results most likely involve a variety of complex protein barrier mechanisms including cyclin-dependent kinase protein, cell-cycle arrest, matric-metalo protein (MMP), Akt/PKB signal transduction, NF-kB transcription factor, and proaptoptosis protein. ${ }^{16}$ It was reported docetaxel was able to induce KB cell apoptosis through intrinsic mitochondrial pathways and increase in vivo antitumor activity. ${ }^{20}$

An in vivo tumorigenesis analysis in experimental animal model in this study demonstrated the potential of docetaxel hydrate in suppressing tumor volume. This result was evidenced by the magnitude of tumor growth inhibition by $62.5 \%$. In the present study, there were no burns or necrosis on the flanks of mice due to treatment and no Raji cell metastasis was found in local, regional or distant lymph nodes. This study was discontinued on the $15^{\text {th }}$ day due to an increasingly smaller tumor volume especially tumors treated with concentration $5.0 \times 10^{-2} \mathrm{M}$ and a positive control because the tumor tissue will be used for further research like immunohistochemistry that requires cancer tissue nodules. It has been reported that the potential of docetaxel hydrate in vivo is highly effective in several types of human cancers including nonsmall cell lung cancer, ${ }^{24}$ glioma, ${ }^{25}$ prostate cancer, ${ }^{6}$ breast, ${ }^{7}$ and oral cancer. ${ }^{5}$

Recent study reported Docetaxel hydrate caused cell cycle inhibition in G2-M phase and induced apoptosis of renal cancer cells by inhibiting the path of mitogen activated protein kinase (MAPK). ${ }^{21}$ The inhibition of cell cycle in G2-M phase was accompanied also by the complex constraints of CDK-1 and cyclin B. Decreased expression of cell cycle proteins is known to activate the cyclindependent kinase inhibitor protein p27Kip1 as a negative regulator of cell cycle that can increase cell growth resistance and induction of apoptosis in oral cancers of the squamous carcinoma and salivary gland cancers. ${ }^{22,23}$

In this study, only concentration difference with the same time (48 hours incubation) was observed. The results revealed the more docetaxel concentration increases the greater the activity of cell apoptosis. The concentrations used for apoptosis analysis had not shown yet that the cells were saturated. It was proofed by increasing apoptotic activity in accordance with concentration elevated. So it is recommended for further research to use larger and broader docetaxel concentrations to produce docetaxel saturation concentrations of oral Burkitt's lymphoma cells. Obstacles in this study include the provision of materials and research tools that require a long time, the place of research must be queued up and inefficient the bureaucracy of correspondence related to research, as well as limited funding and research time. To address these weaknesses, a research strategy has been carried out by coordinating affiliation with research institutions within the Gadjah Mada University, so that the materials, tools, places and locations of the research that become obstacles are easily solved. In addition, a long-term published correspondence on research permits to be quick published using the personal recommendations of faculty leaders.

\section{CONCLUSION}

Docetaxel hydrate has a high antitumour potency by inhibiting tumorigenesis and increasing apoptosis of Burkitt's lymphoma cells.

\section{ACKNOWLEDGEMENT}

This research was supported by Dana Masyarakat 2017, Faculty of Dentistry, Gadjah Mada University, Indonesia. 


\section{REFERENCES}

1. Gopal S, Gross TG. How I treat Burkitt lymphoma in children, adolescents, and young adults in sub-Saharan Africa. Blood. 2018; 132(3): 25463. DOI: $10.1182 /$ blood-2018-04-844472

2. God JM, Haque A. Burkitt Lymphoma: Pathogenesis and Immune Evasion. J Oncol. 2010; 2010: 1-14. DOI: 10.1155/2010/516047

3. Salamon D, Adori $M$, He $M$, Bonelt $P$, Severinson $E$, Kis $L L$, et al. Type I interferons directly down-regulate BCL-6 in primary and transformed germinal center $B$ cells: Differential regulation in $B$ cell lines derived from endemic or sporadic Burkitt's lymphoma. Cytokine. 2012; 57(3): 360-71. DOI: 10.1016/j. cyto.2011.12.001

4. Rowe M, Fitzsimmons L, Bell Al. EpsteinBar virus and Burkitt's lymphoma. Chin J Cancer. 2014; 33(12): 609-19. DOI: 10.5732/ cjc. 014.10190

5. Nafianti S, Windiastuti E, Gatot D. 2008. Gambaran Limfoma Burkitt di Departemen Ilmu Kesehatan Anak RSUP Cipto Mangunkusumo Jakarta. Sari Pediatri. 2008; 10(1): 47-52. DOI: $10.14238 / \mathrm{sp} 10.1 .2008 .47-52$

6. Supriatno. Docetaxel hidrat menghambat proliferasi dan metastasis sel kanker oral melalui induksi protein Maspin. J Dent Ind. 2008; 15(1): 2-7. DOI: 10.14693/jdi.v15i1.77

7. O'NeillAJ, Prencipe M, Dowling C, Fan Y, Mulrane L, Gallagher WM, et al. Characterisation and manipulation of docetaxel resistant prostate cancer cell lines. Mol Cancer. 2011; 10: 126. DOI: $10.1186 / 1476-4598-10-126$

8. Zhang $X$, Zhang S, Liu Y, Liu J, Ma Y, Zhu Y, et al. Effects of the combination of RAD001 and docetaxel on breast cancer stem cells. Eur J Cancer. 2012; 48(10): 1581-92. DOI: 10.1016/j.ejca.2012.02.053

9. Wada Y, Yoshida K, Suzuki T, Mizuiri H, Konishi K, Ukon K, et al. Synergistic effects of docetaxel and $\mathrm{S}-1$ by modulating the expression of metabolic enzymes of 5-fluorouracil in human gastric cancer cell lines. Int J Cancer. 2006; 119(4): 783-91. DOI: 10.1002/ijc.21879

10. Mhaidat NM, Wang Y, Kiejda KA, Zhang XD, Hersey P. Docetaxel-induced apoptosis in melanoma cells is dependent on activation of caspase-2. Mol Cancer Ther. 2007; 6(2): 75261. DOI: 10.1158/1535-7163.MCT-06-0564

11. Friedlander RM. Apoptosis and caspases in neurodegenerative disease. $\mathrm{N}$ Engl J Med. 2003; 348(14): 1365-75. DOI: 10.1056/ NEJMra022366

12. Elmore S. Apoptosis: A review of programmed cell death. Toxicol Pathol. 2007; 35(4): 495516. DOI: $10.1080 / 01926230701320337$

13. Supriatno, Harada K, Hoque MO, Bando T, Yoshida $\mathrm{H}$, Sato $M$. Overexpression of p27Kip1 induces growth arrest and apoptosis in an oral cancer cell line. Oral Oncol. 2002; 38(7): 7306. DOI: 10.1016/S1368-8375(02)00011-8

14. Benes FM, Matzilevich D, Burke RE, Walsh J. The expression of proapoptosis genes is increased in bipolar disorder, but not in schizophrenia. Mol Psychiatry. 2006; 11(3): 241-51. DOI: $10.1038 /$ sj.mp.4001758

15. Croce $C M$. Oncogenes and cancer. $N$ England J Med. 2008; 358(5): 502-11. DOI: 10.1056/ NEJMra072367

16. Omotehara F, Kawamata H, Uchida D, Hino $S$, Nakashiro K, Fujimori T. Vesnarinone, a differentiation inducing drug, directly activates $\mathrm{p} 21$ waf1 gene promoter via Sp1 sites in a human salivary gland cancer cell line. $\mathrm{Br}$ J Cancer. 2002; 87(9): 1042-6. DOI: 10.1038/ sj.bjc. 6600592

17. Supriatno, Harada K, Yoshida H, Sato M. 2005. Basic investigation on the development of molecular targeting therapy against cyclindependent kinase inhibitor p27Kip1 in head and neck cancer cells. Int J Oncol 27: 627-635.

18. Baker SD, Sparreboom A, Varweij J. 2006. Clinical Pharmacokinetics of Docetaxel. Recent Developments. Clin Pharmacokinet 45 (3): 235-252.

19. Lyseng-Williamson KA, Fenton C. 2005. Docetaxel: a review of its use in metastatic breast cancer. Drugs 65: 2513-2531.

20. Munkarah AR, Ali-Fehmi R, Jiang JZ, Elhammady E, Malone JM, Saed GM. 2007. The effects of combining docetaxel and cyclooxygenase- 2 inhibitors on proliferation and apoptosis in epithelial ovarian cancer. Anticancer Drug 18: 889-896.

21. Tao J, Xu J, Chen F, Xu B, Gao J, Hu Y. 2017. Folate acid-Cyclodextrin/Docetaxel 
induces apoptosis in KB cells via the intrinsic mitochondrial pathway and displays antitumor activity in vivo. Eur J Pharm Sci. S09280987(17): 30614-20.

22. Han TD, Shang DH, Tian Y. 2016. Docetaxel enhances apoptosis and G2/M cell cycle arrest by suppressing mitogen-activated protein kinase signaling in human renal clear cell carcinoma. Genet Mol Res.15(1): 1-10.

23. Harada K, Supriatno, Kawaguchi S, Onoue T, Kawashima Y, Yoshida H and Sato M.2005. High antitumor activity using intratumoral injection of plasmid DNA with mutant-type p27Kip1 gene following in vivo electroporation. Oncol Rep 13: 201-206.

24. Supriatno, Harada K, Kawaguchi S, Yoshida H, Sato M. 2003. Effect of p27Kip1 on the ability of invasion and metastasis of an oral cancer cell line. Oncol Rep 10:527-532.

25. Ichite $\mathrm{N}$, Chougule MB, Jackson T, Fulzele SV, Safe S, Singh M. 2009. Enhancement of docetaxel anticancer activity by a novel diindolylmethane compound in human nonsmall cell lung cancer. Clin Cancer Res. 15(2):543-52

26. Gaoe H, Pang Z, Pan S, Cao S, YangZ, Chen C, Jiang X. 2012. Anti-glioma Effect and Safety of Docetaxel-loaded Nanoemulsion. Arch Pharm Res. 35(2):333-41

27. Huang GC, Liu SY, Lin MH, Kuo YY, Liu YC. 2004. The synergistic cytotoxicity of cisplatin and taxol in killing oral squamous cell carcinoma. Jpn J Clin Oncol. 34(9): 499-504 